
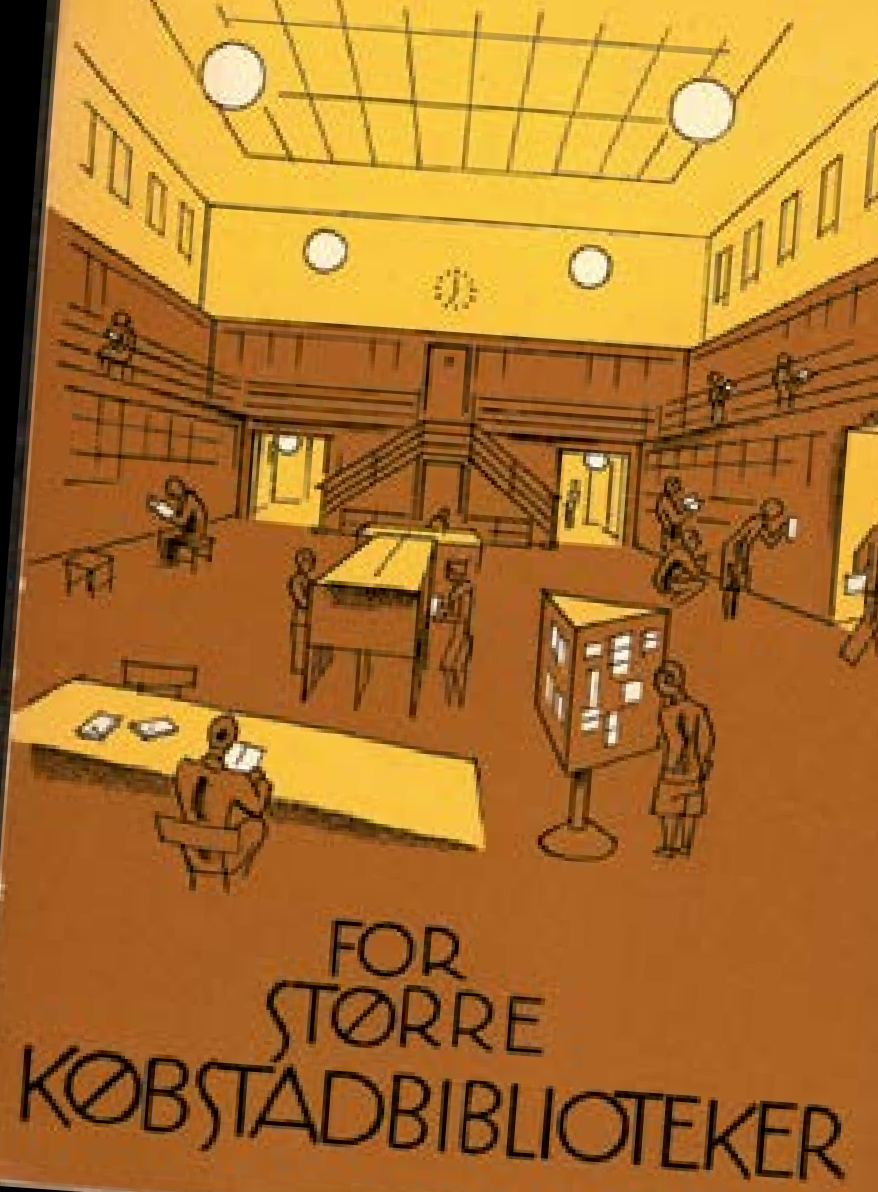

Mønsterkatalog. Forside af Fælleskatalog for Større Købstadsbiblioteker fra 1939 med Frederiksberg Bibliotek i Axel Nygaards moderne streg. (Dansk Bibliotekshistorie, bind Il, s. 69)

\title{
1.000 års bibliotekshistorie
}

Udgivelsen af Dansk Bibliotekshistorie I-II er omtalt i dette nummer af REVY, som også har en samtale med to af de bidragydere til værket.

En anmeldelse af tobindsværket følger i REVY 1/2022.

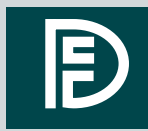

DFFU SEKRETARIET

C/O Syddansk

Universitetsbibliotek

Studiestræde 6

1456 København K

\section{DFFU-ARRANGEMENTER:}

3.-4. marts 2022

Vinterinternat på Klarskovgaard ved Korsør.

Tema: Det indlejrede bibliotek.

Tilmelding: dfdf.dk.

\section{6.-8. juli 2022}

LIBER (Ligue des Bibliothèques Européennes de Recherche - Association of European Research Libraries) Annual Conference 2022 - SDU/Odense 